\title{
Innate immunity gene expression changes in critically ill patients with sepsis and disease-related malnutrition
}

\author{
ROBERT SŁOTWINSKKI ${ }^{1,2}$, AGNIESZKA SARNECKA ${ }^{1}$, ALEKSANDRA DĄBROWSKA ${ }^{2}$, \\ KATARZYNA KOSAEKA', EWELINA WACHOWSKA2, BARBARA J. BAEAN', \\ MARTA JANKOWSKA², TERESA KORTA ${ }^{3}$, GRZEGORZ NIEWINSSKI ${ }^{3}$, ANDRZEJ KAŃSKI \\ MAEGORZATA MIKASZEWSKA-SOKOLEWICZ ${ }^{4}$, MOHAMMAD OMIDI ${ }^{5}$, KRYSTYNA MAJEWSKA \\ SYLWIA M. SŁOTWINSSKA
}

'Department of Surgical Research and Transplantology, Mossakowski Medical Research Center, Polish Academy of Sciences, Warsaw, Poland

${ }^{2}$ Department of Immunology, Biochemistry and Nutrition, Medical University of Warsaw, Poland

${ }^{3}$ Second Department of Anesthesiology and Intensive Care, Medical University of Warsaw, Poland

${ }^{4}$ First Department of Anesthesiology and Intensive Care, Medical University of Warsaw, Poland

${ }^{5}$ Department of General Surgery and Nutrition, Medical University of Warsaw, Poland

${ }^{6}$ Department of Conservative Dentistry, Medical University of Warsaw, Poland

\begin{abstract}
The aim of this study was an attempt to determine whether the expression of genes involved in innate antibacterial response (TLR2, NOD1, TRAF6, HMGB1 and Hsp70) in peripheral blood leukocytes in critically ill patients, may undergo significant changes depending on the severity of the infection and the degree of malnutrition. The study was performed in a group of 128 patients with infections treated in the intensive care and surgical ward. In 103/80.5\% of patients, infections had a severe course (sepsis, severe sepsis, septic shock, mechanical ventilation of the lungs). Clinical monitoring included diagnosis of severe infection (according to the criteria of the ACCP/SCCM), assessment of severity of the patient condition and risk of death (APACHE II and SAPS II), nutritional assessment (NRS 2002 and $S G A$ scales) and the observation of the early results of treatment. Gene expression at the mRNA level was analyzed by real-time PCR. The results of the present study indicate that in critically ill patients treated in the ICU there are significant disturbances in the expression of genes associated with innate antimicrobial immunity, which may have a significant impact on the clinical outcome. The expression of these genes varies depending on the severity of the patient condition, severity of infection and nutritional status. Expression disorders of genes belonging to innate antimicrobial immunity should be diagnosed as early as possible, monitored during the treatment and taken into account during early therapeutic treatment (including early nutrition to support the functions of immune cells).
\end{abstract}

Key words: gene expression, innate immunity, malnutrition, sepsis.

(Cent Eur J Immunol 2015; 40 (3): 311-324)

\section{Introduction}

Although the methods of treatment of critically ill patients, major trauma, sepsis, septic shock and multi organ failure are improving, they are still burdened with high mortality. The highest mortality rate is recorded in patients with severe infections and septic shock (30-50\%) treated in intensive care units (ICU) [1-5]. Previous attempts to introduce new, more effective therapies to support basic treatment were focused primarily on reducing excessive inflammatory response to injury and infection (e.g., by blocking inflammatory mediators, including the use of recombinant human activated protein/rhAPC/Xigris, talactoferrin or anti-endotoxin antibodies) [6-8]. These methods were based on the promising results of experimental studies and clinical trials (tested in Phase III human clinical trials) and had little impact on improving treatment results; their application in some septic patients turned out to be harmful, which caused their withdrawal from the ICU. Other promising attempts to improve the results of treatment of critically ill patients with infections by blocking receptor signaling pathways of innate

Correspondence: Robert Słotwiński, Department of Immunology, Biochemistry and Nutrition, Medical University of Warsaw, Oczki 3, 02-007 Warsaw, Poland, e-mail: robert_slotwinski@yahoo.com 
antibacterial response (e.g., TLR4 receptor blockade by antagonists: Eritoran-E5564 or Resatorvid-TAK242) also did not live up to expectations [9]. The results of these studies clearly indicated the high complexity of the mechanisms of immune response to trauma and infection requiring better understanding and detailed reassessment in specific clinical situations. The classical concept of SIRS/CARS reactions (systemic inflammatory response syndrome/compensatory antiinflammatory response syndrome) to trauma and infection, which has been frequently modified, was once more verified [10-14]. The results showed that the interpretation of the immune response to trauma and infection, based on the "decisive for the course of the disease" excessive inflammatory response syndrome (SIRS/“cytokine storm”) was insufficient and was not confirmed by the efficacy of biological treatment methods in severe infections. In sepsis prognosis and attempts to improve outcomes of the treatment (e.g., by regulating lymphocyte apoptosis or stimulating their functions) more attention was focused on the contribution of cellular immune disorders, immunosuppression development and genetic determinants of immune response (e.g., genetic polymorphisms in the components of the inflammatory and/or immune response) [15-24]. However, attention was also paid to other factors, and it was found that the malnutrition associated with sepsis had a particularly significant impact on cellular immunity disorders and was an important factor increasing mortality [25-28]. Nutritional disorders have been most commonly reported in critically ill patients with infections and the PICS syndrome (persistent inflammation and immune suppression catabolism syndrome) treated for extended periods of time (usually more than 14 days) in intensive care or surgery units; the concentration of c-reactive protein $>150 \mathrm{mg} / \mathrm{dl}$, total lymphocyte count $<800 / \mathrm{mm}^{3}$, weight loss $>10 \%$ during hospitalization, BMI $<18 \mathrm{~kg} / \mathrm{m}^{2}$, and reduced albumin $(<3 \mathrm{gm} / \mathrm{dl})$ and prealbumin levels $(<20 \mu \mathrm{g} / \mathrm{dl})$ [14]. Numerous studies assessing the nutritional status found that the risk of malnutrition in the ICU occurs in a fairly wide range (6-42\%), but depending on the studied group of patients may affect up to $100 \%$ of subjects [29-35].

It was shown that the application of different forms of nutritional therapy in critically ill patients (e.g., enteral-immunonutrition) could have a significant impact on the improvement of the clinical outcome [36-40]. The failure of nutritional therapy in septic patients was most often explained by the uncontrolled exacerbation of inflammation (e.g., increased concentrations of TNF- $\alpha$, IL-1 $\beta$, IL-6 or IL-8 after administration of lipid emulsions containing n-6 PUFA), elevated levels of nitric oxide after high doses of arginine and an increase in oxidative stress (reactive oxygen species can react with the double bond of unsaturated lipids and damage cell membranes, lipids, proteins and DNA through oxidation) and intensification of immunosuppression (reduced migration and phagocytic activity of neutrophils and macrophages, decreased lymphocyte reac- tivity to microbial antigens and inhibition of antibody-dependent cellular cytotoxicity) during the administration of high doses of polyunsaturated fatty acids (e.g., n-6 PUFA), which was reflected in the recommendations of international food societies on the use of immunonutrition in the ICU [41-52]. An increase in mortality was also reported in critically ill patients treated in the ICU following high glutamine doses [53]. Despite the initial optimistic results of studies on immunonutrition, the concept of limiting interference with immune functions in patients with severe infections by the use of ,immunoneutral" nutritional mixtures (e.g., containing MCT/LCT, n-9 MUFA fatty acids and antioxidants/selenium) has gained many supporters, but (as previous methods) has not solved the problem of high mortality in ICU patients [52, 54-57].

A new direction of genetic research conducted in a group of critically ill patients after trauma, with infections, where the participation of antimicrobial innate immune disorders is emphasized, has raised some hopes for the improvement of treatment outcomes [24, 58-64]. Advanced research methodology (e.g., microarray and GeneChip technology) enables the assessment of expression of more than 100 or several thousand genes, which provides rapid insight into the dynamics of the inflammatory response to infection [24, 64]. In sepsis, a large number of transcripts associated with inflammation and innate immunity were shown to be substantially up-regulated, while in parallel, several gene programs led to repression of adaptive immunity.

Our concept concerning critically ill patients with severe infections assumes focusing on the attempts to modulate the expression of signaling pathway proteins in the cells participating in the elimination of microorganisms as well as in local and systemic inflammatory response regulation, wich increases the risk of multiple organ failure (MOF). Innate immune cells (neutrophils, monocytes/ macrophages, NK cells) initially recognize and are activated by pathogen-associated molecular patterns (PAMPs) or endogenous alarmins and danger signaling [65-67]. The functions of these cells as a result of extensive trauma, infection, protein catabolism and reduced levels of nutritional substances (e.g., glutamine, arginine) are disturbed (e.g., the disorders of expression of bacterial antigen-binding extracellular receptors and intracellular proteins/receptors), which is one of the most important factors exacerbating immunosuppression, delaying wound healing and being conducive to severe infections [57, 68-76]. This problem affects mainly patients in the critical condition with persistent infections requiring intensive care. We believe that the modulation of Toll-like receptor expression, which bind bacterial antigens and are present in the cells of intestinal mucous membrane, neutrophils, monocytes and dendritic cells as well as the modulation of expression of signaling pathway proteins in those cells by early administration of appropriate enteral nutritional support, can 
help efficiently eliminate microorganisms, reduce inflammatory response and immunosuppression [73, 77-80]. This concept is particularly important in view of the increasing resistance of microorganisms to antibiotics, immuno-compromised critically ill patients with severe malnutrition and the dysfunction of gut-associated lymphoid tissue (GALT) as well as the low effectiveness of the existing nutritional treatment methods in this group of patients. Increasing the effectiveness of the treatment in these patients, including nutritional therapy, requires a better understanding of the genetic basis of antimicrobial innate immune disorders.

The objective of this study was an attempt to determine whether the expression of genes involved in innate antibacterial response (TLR2, NOD1, TRAF6, HMGB1 and Hsp70) in peripheral blood leukocytes in critically ill patients, may undergo significant changes depending on the severity of the infection and the degree of malnutrition. The selection of genetic parameters studied was based on the results of our previous studies conducted in malnourished patients $[81,82]$.

\section{Material and methods}

The study was performed in a group of 128 patients with infections, aged from 16 to 87 years, with an average age of $54.6 \pm 18.2$ ( 35 women and 93 men), treated in the intensive care unit (ICU) and the surgical ward. The study included a group of critically ill surgical patients with late occuring septic complications after major abdominal surgeries, reoperations, with severe complications of acute pancreatitis, infections from other causes (mainly with severe respiratory and urinary tract infections), patients with septic infections of catheters for parenteral nutritional therapy at home and people after multiorgan traumas admitted directly to the ICU. In $103 / 80.5 \%$ of the patients, infections had a severe course (sepsis, severe sepsis, septic shock, mechanical ventilation of the lungs). In this group $29 / 28 \%$ of the patients died within 7 days of treatment in the ICU, including 9 subjects with severe complications of acute pancreatitis, 6 patients after major cancer surgeries and a mixed group of patients with complications after a liver transplant, vascular transplants, respiratory and urinary tract infections. Microbiological analysis in patients with severe infections found 120 strains of Gram-negative bacteria, 91 strains of Gram-positive bacteria, and fungi in 33 cases (mainly of the Candida glabrata species). No septic infections were found in the remaining $25 / 19.5 \%$ of critically ill patients. The study protocol excluded patients after chemo- or radiotherapy, patients with advanced cancer disease, chronic liver and kidney disease, diabetes type I and chronic steroid therapy before admission to the ward. The control group consisted of 30 healthy volunteers in a similar age and gender range as the study group.

Clinical monitoring of patients included observation of the early results of treatment (including mortality rate), the routine evaluation of the patient health condition and the risk of death according to APACHE II and SAPS II scales, performed by the anesthesiologist as well as nutritional assessment carried out by a dietitian within 48 hours of admission to the ward (including Nutritional Risk Screening - NRS 2002 and Subjective Global Assessment - SGA scale) $[83,84]$. The diagnosis of severe infection cases with symptoms of systemic inflammatory response syndrome (SIRS), sepsis, severe sepsis, septic shock, was based on diagnostic criteria adopted by the ACCP/SCCM (American College of Chest Physicians/Society of Critical Care Medicine), Polish Working Group for Sepsis and Polish Society of Interdisciplinary Intensive Therapy [85-87].

\section{Sample collection and leukocyte isolation}

Blood samples were obtained from the peripheral vein of critically ill patients and healthy volunteers as controls. Leukocytes were isolated from $10 \mathrm{ml}$ of heparinized blood using Polymorphprep (AXIS-SHIELD PoC AS, Oslo, Norway). Briefly, blood was layered over Polymorphprep and centrifuged at room temperature $(500 \times \mathrm{g} / 35 \mathrm{~min})$. The resulting mono- and polymorphonuclear leukocyte fractions were harvested, washed in the PBS solution to remove plasma and anticoagulant residues, suspended in a suitable medium and immediately frozen at $-70^{\circ} \mathrm{C}$, until used in further analysis.

\section{RNA extraction and reverse transcription}

Total RNA was extracted from leukocytes using the Total RNA Mini Isolation Kit (A\&A Biotechnology, Poland) according to manufacturer's instructions. Isolated RNA was evaluated qualitatively and quantitatively using a NanoDrop spectrophotometer (Thermo Fisher Scientific Inc., Waltham, MA, USA). Then the first-strand cDNA was synthesized by using VerteKit (Novazym, Poznań, Poland). Briefly, $5 \mu \mathrm{g}$ total RNA was incubated at $70^{\circ} \mathrm{C}$ for 5 minutes with oligo $(\mathrm{dT})_{15}$ primers. Afterwards, M-MLV buffer, dNTPs mix and Malooney Murine Leukemia Virus reverse transcriptase were added and the mix was incubated at $37^{\circ} \mathrm{C}$ for 60 minutes. Reaction was terminated by 10 -minute incubation at $70^{\circ} \mathrm{C}$. The reverse transcription products were analyzed again on a NanoDrop spectrophotometer.

\section{Real-time PCR}

Real-time PCR was performed using a LightCycler 1.5 Instrument and LightCycler ${ }^{\circledR}$ FastStart DNA Master SYBR Green I detection kit (Roche Applied Science, Basel, Switzerland, Cat. No. 12239264 001) as per the manufacturer's protocol. The final $20 \mu \mathrm{l}$ real-time PCR reaction included $500 \mathrm{ng} / \mu \mathrm{l} \mathrm{RT}$ product, $2 \mu \mathrm{l}$ of primers, $0.8 \mu \mathrm{l}$ of $\mathrm{MgCl}_{2}$ and $2 \mu \mathrm{l}$ of LightCycler ${ }^{\circledR}$ FastStart DNA Master SYBR Green I. DNase-RNase-free distilled water was added to a total volume of $20 \mu \mathrm{l}$ per capillary. The re- 
Table 1. Primer sequences and optimized annealing temperatures used in the real-time PCR reaction

\begin{tabular}{lccc}
\hline Gene & Forward sequence & Reverse sequence & Annealing temperature \\
\hline TLR2 & 5'-TCCATCCCATGTGCGTGGCC-3' & 5'-CAGGACCCCCGTGAGCAGGAT-3' & $59^{\circ} \mathrm{C}$ \\
\hline NOD1 & 5'-GCCCCGCGTTCAGGTCGAAA-3' & 5'-GTGAGGCGGCTGAAGCAGGG-3' & $61^{\circ} \mathrm{C}$ \\
\hline TRAF6 & 5'-AGGGACCCAGCTTTCTTTGTGTGC-3' & 5'-CCGTGCGTGGCAGTTCCACC-3' & $62^{\circ} \mathrm{C}$ \\
\hline HMGB1 & 5'-GGCAAGTGAGAGCCGGACG-3' & 5' -GCTTCTTCTTATGCTCCTCCCGACA-3' & $62^{\circ} \mathrm{C}$ \\
\hline HSP70 & 5'-CCATCATCAGCGGACTGTACC-3' & 5'-CTGACCCAGACCCTCCCTT-3' & $59^{\circ} \mathrm{C}$ \\
\hline GAPDH & 5'-GTGAAGCAGGCGTCGGAGGG-3' & 5'-GCTCTTGCTGGGGCTGGTGG-3' & $59^{\circ} \mathrm{C}, 61^{\circ} \mathrm{C}$ and $62^{\circ} \mathrm{C}$ \\
\hline
\end{tabular}

action was run as follows: $95^{\circ} \mathrm{C}$ for $10 \mathrm{~min}$, followed by 50 denaturation cycles at $95^{\circ} \mathrm{C}$ for $15 \mathrm{~s}$, appropriate annealing temperature (Table 1) for $10 \mathrm{~s}\left(60 \mathrm{~s}\right.$ for Hsp70) and $72^{\circ} \mathrm{C}$ extension step for $15 \mathrm{~s}$. After 50 cycles, a melting curve was generated by slowly increasing $\left(0.2^{\circ} \mathrm{C} / \mathrm{s}\right)$ the temperature from $70^{\circ} \mathrm{C}$ to $99^{\circ} \mathrm{C}$, and measuring fluorescence. In each assay, mRNA levels of GAPDH as well as TLR2, NOD1, HMGB1, and TRAF6 genes were measured simultaneously under identical conditions. The primer sequences and annealing temperatures are summarized in Table 1.

The results were analyzed using the double delta method, assuming that the expression of the gene in the treated groups is $2^{-\Delta \Delta \mathrm{Ct}}$, where $\Delta \Delta \mathrm{Ct}=[\mathrm{Ct}$ target gene $-\mathrm{Ct}$ GAPDH $]$ is the treated sample, and [Ct target gene - $\mathrm{Ct}$ GAPDH] is the control sample [88]. Each experiment was carried out in triplicate using GAPDH as internal standard. This calculation formula shows the expression of the gene in the tested group as multiples of the control group expression. The results are presented as the mean of the measurements \pm standard deviation.

\section{Ethics}

The study protocol was approved by the Medical University Ethics Committee and conforms to the ethical guidelines of the World Medical Association Declaration of Helsinki.

\section{Statistical analysis}

Statistical analysis was performed using Statsoft Statistica v.9.0 software. Mann-Whitney $U$ test was used to evaluate the statistical significance between the gene expression in the tested groups of patients. Differences at $p<0.05$ were considered to be statistically significant.

\section{Results}

\section{Assessment of nutritional status}

Analysis of the nutritional status carried out in all patients $(n=128)$ revealed that $60 / 47 \%$ had severe malnutrition (NRS 2002 in the range of 5-7 points, an average score of $6 \pm 0.9$, SGA group C), 46/36\% moderate malnutrition (NRS 2002 in the range of 3-4 points, an average score of $3.7 \pm 0.5$, SGA group B), and the remaining $22 / 17 \%$ of patients had mild malnutrition or normal nutritional status (NRS 2002 in the range of 0-2 points, SGA group A). In patients with severe infections $(n=103$ : severe sepsis, septic shock, ventilator, APACHE II score $=24.39 \pm 11.7$, SAPS II score $42.93 \pm 18.9$ ), in $60 / 58 \%$ severe malnutrition was observed, $32 / 31 \%$ moderate malnutrition, and $11 / 11 \%$ of the patients had mild malnutrition or normal nutritional status. In this group of patients, 29/28\% of them died (APACHE II score $=28.96 \pm 9.8$ and SAPS II score $=51.50 \pm 18.5$ ) in the first week of treatment due to multiple organ failure (MOF). Of the patients who died, 26/86\% had severe malnutrition and 3 moderate malnutrition. In the remaining group of critically ill patients $(n=25$, with APACHE II score of $19 \pm 6.6$ and SAPS II score of 40.9 \pm 12.7 ) without symptoms of severe septic infections, moderate malnutrition was observed in 14 patients (NRS 2002 score was on average $3.5 \pm 0.4$ points, SGA group B), and in 11 patients the nutritional status was normal. One subject in this group died.

\section{Genetic analysis}

The whole group of critically ill patients showed a significantly elevated expression of TLR2, NOD1 and Hsp70 genes, and a significantly reduced expression of TRAF6 and HMGB1 genes (for all measurements $p<0.05$ ). To examine the impact of severe infections on the gene expression, the group of critically ill patients with severe infections (sepsis, severe sepsis, septic shock, including mainly patients with severe malnutrition) was compared with a group of critically ill patients without severe septic infections (patients with moderate or mild malnutrition or normal nutritional status). It was found that patients with serious infections and APACHE II score $>20$ points, had a significantly reduced expression of TLR2 $(p=0.00001)$, HMGB1 $(p=0.002)$, and Hsp70 genes $(p=0.002)$, while the expression of the NOD1 gene was markedly elevated ( $p=0.01$ ) (Fig. 1A-D). Differences in the TRAF6 gene expression were not statistically significant. Similar changes in gene expression were found when comparing the group of patients with severe infections and the control group.

In order to investigate the effect of the nutritional status on the expression of the genes examined, the group of 

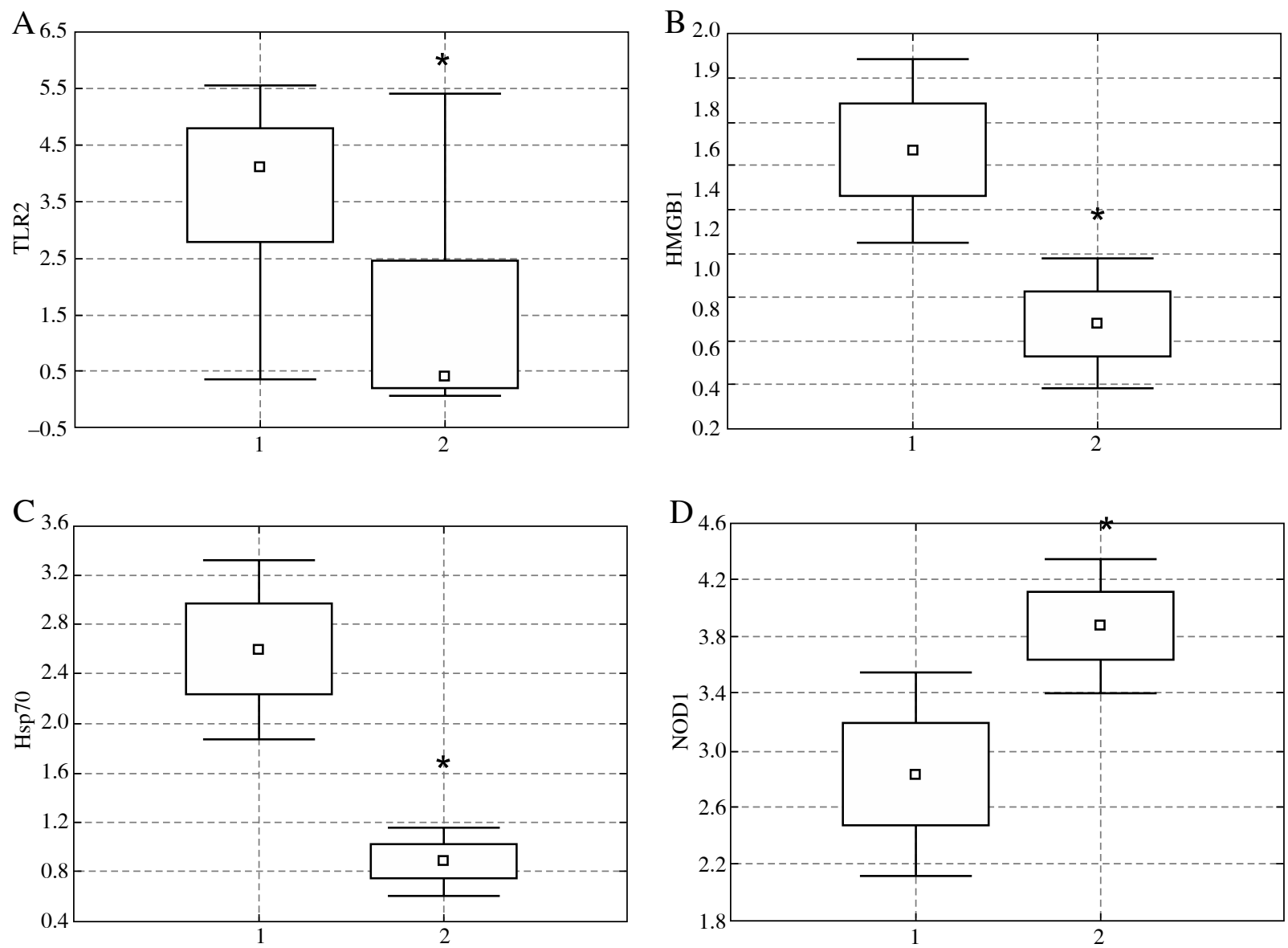

Fig. 1A-D. Expression of genes encoding TLR2, HMGB1, Hsp70 and NOD1 proteins in patients without severe septic infections (1) compared with patients with severe infections $(2)(* p<0.05)$

patients with serious infections and severe malnutrition $(n=60$, APACHE II score $=28.66 \pm 10.4$ SAPS II score $=48.78 \pm 16.1$ ) was compared with the group of subjects with severe infections (comparison within the same group of patients with severe infections), who had a moderate malnutrition (n-46, APACHE II score $=21.26 \pm 9.6$, SAPS II score $=41.56 \pm 16.5$ ). Patients with severe infections and severe malnutrition had a significantly lower expression of TLR2 $(p=0.0004)$, TRAF6 $(p=0.006), H M G B 1(p=0.002)$ and $H s p 70$ genes $(p=0.0001)$, while the differences in NOD1 expression were statistically insignificant (Fig. 2A-D). However, when compared with the control group, NOD1 expression in patients with severe malnutrition was significantly increased $(p=0.00000)$, and the expression of TRAF6, HMGB1 and $H s p 70$ genes was similarly significantly reduced (for all measurements $p<0.05$ ), while the expression of TLR2 was normal.

The expression of TLR2 $(p=00001)$ and NOD1 genes ( $p=0.00004)$ was significantly higher in patients with moderate malnutrition compared to patients with mild mal- nutrition or normal nutritional status (APACHE II score $=13.18 \pm 6.8$, SAPS II score $=27.54 \pm 13.5$ ), while the expression of other genes was not significantly different (Fig. 3A, B). In patients with mild malnutrition or normal nutritional status, the expression of TLR2 and NOD1 genes did not deviate from the norm, while the Hsp70 gene expression was significantly increased $(p=0.0000)$.

In deceased patients with severe infections, gene expression was not significantly different compared to critically ill patients who survived the infection. Comparison of the gene expression between the early death group with severe infection and malnutrition and the group of patients with mild malnutrition or normal nutritional status (1 death in this group) showed a significantly higher expression of TLR2 $(p=0.006)$ and NOD1 genes $(p=0.0001)$ in the group of deceased subjects (Fig. 4). In comparison with the control group, an increased NOD1 gene expression $(p=0.00007)$ and reduced TRAF6 $(p=0.0002)$, and HMGB1 $(p=0.01)$ gene expression was observed in deceased patients. 
A

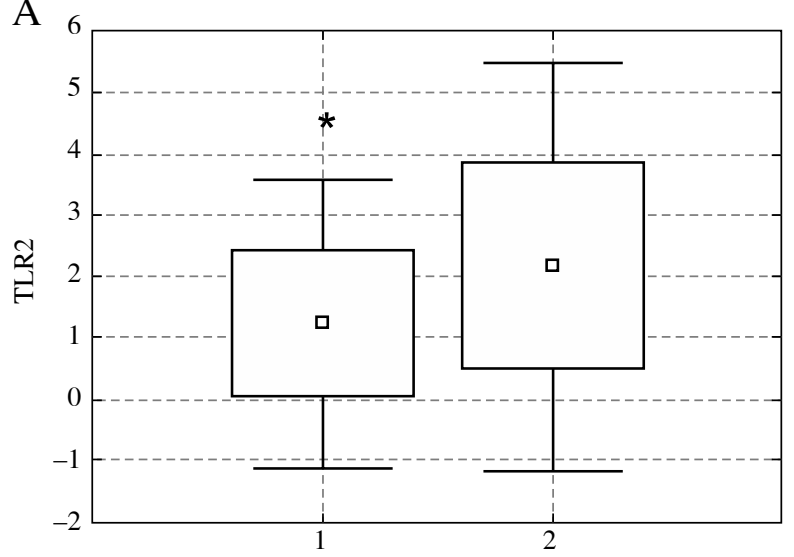

C

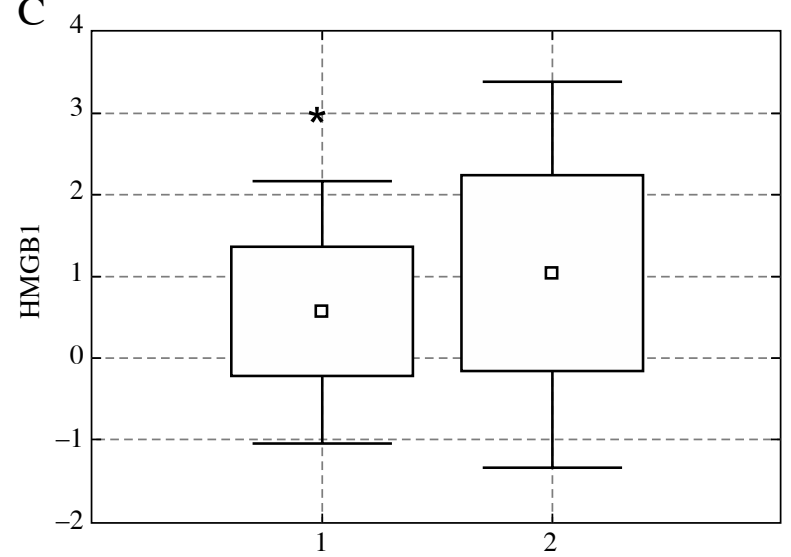

$\mathrm{B}_{2.0}$

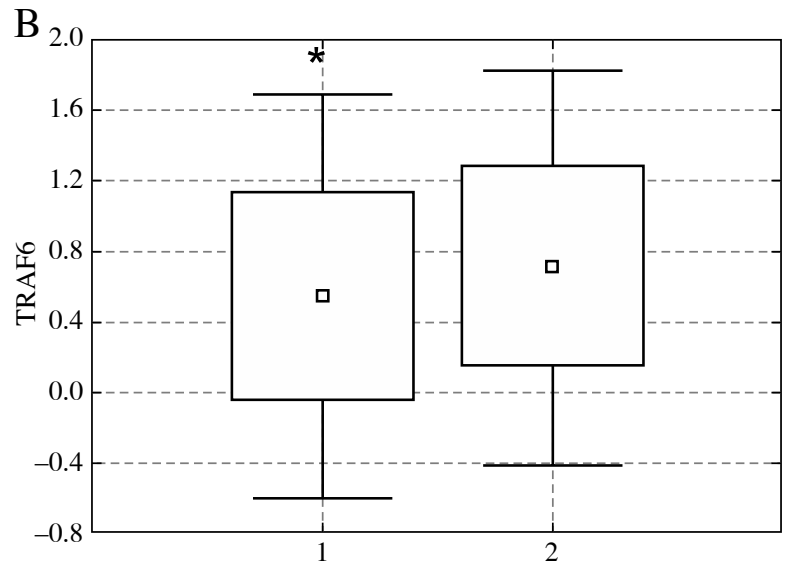

D

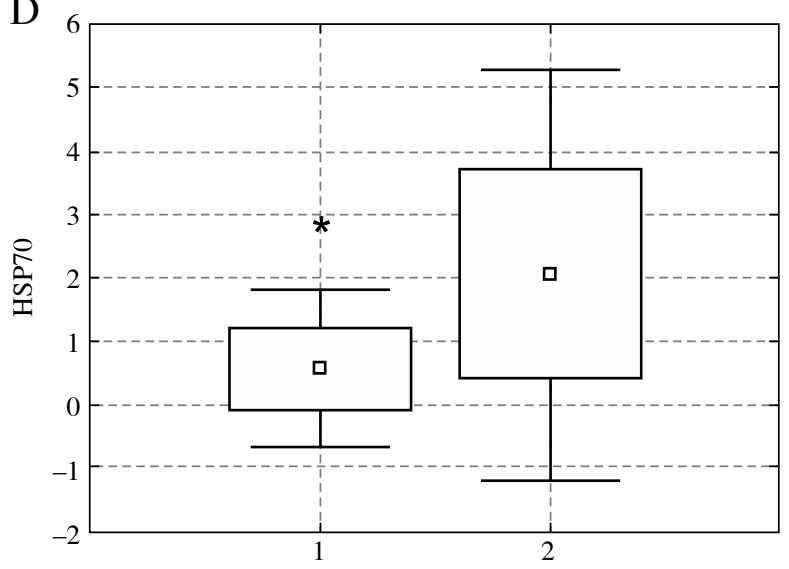

Fig. 2A-D. Expression of genes encoding TLR2, TRAF6, HMGB1 and Hsp70 proteins in patients with severe malnutrition (1) compared to patients with moderate malnutrition $(2)\left({ }^{*} p<0.05\right)$

\section{Discussion}

Considerable diversity of the patient groups studied is a common problem that hinders the assessment of the effectiveness of new treatments and interpretation of the results of molecular tests conducted in the ICUs. Patients treated in the ICU differ significantly in terms of diagnosis, severity of disease, metabolic disorders and therapeutic procedures. Often used terms, such as "critically ill" or "patients from the ICU" do not refer to homogeneous populations. Considering these problems, which are difficult to avoid, particular attention was devoted to diagnostic criteria for the diagnosis of severe infection, the severity of the patients' condition and risk of death, as well as diagnosis of nutritional status disorders based on generally accepted and most frequently used international diagnostic scales. The clinical monitoring of patients was carried out by closely cooperating teams of anesthetists and nutritionists, which in many centers is still not a generally accepted practice, because the importance of professional evaluation of the nutritional status in patients treated in the ICU is underestimated. Severe malnutrition and severe infections leading to high mortality were the main factors "connecting" heterogeneous groups of patients. Moreover, a "common characteristic" in the majority of patients was similar complications after surgical treatment of various diseases requiring admission to the ICU. These patients were treated previously in other surgical wards and had organ damage after major abdominal surgeries, reoperations, including a fairly homogeneous group of patients with septic infections of the catheter for parenteral nutrition at home or a group of patients with severe acute pancreatitis. The current genetic tests were performed at the mRNA level and were preceded by the analysis of changes in the expression of the same genes during treatment (days $1,3,7$ ) and in other groups of patients in order to reduce the impact of other factors on the tested parameters, as it happened many times during our previous studies on inflammatory response mediators [82, 89].

The results of our study clearly show that changes in the expression of genes encoding proteins of innate antibacterial response to trauma and infection in peripheral blood leukocytes of critically ill patients are primarily 
A

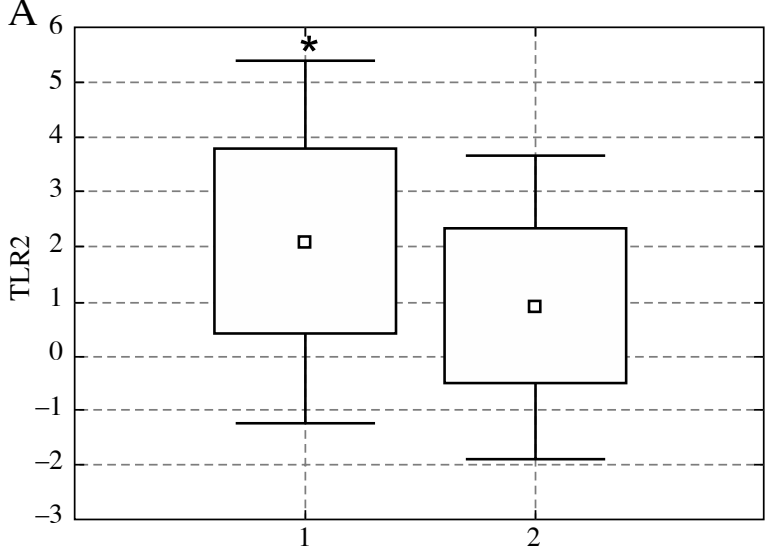

B

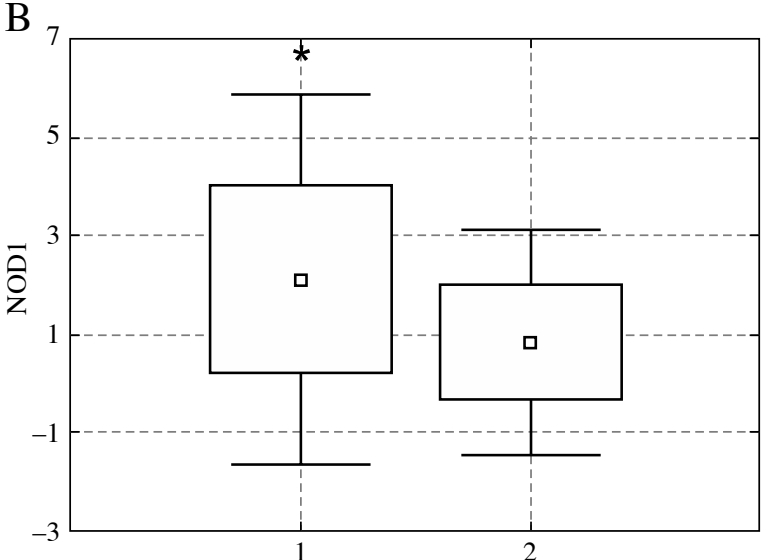

Fig. 3A, B. Expression of genes encoding TLR2 and NOD1 proteins in patients with moderate malnutrition (1) compared to patients with mild malnutrition or normal nutritional status $(2)(* p<0.05)$

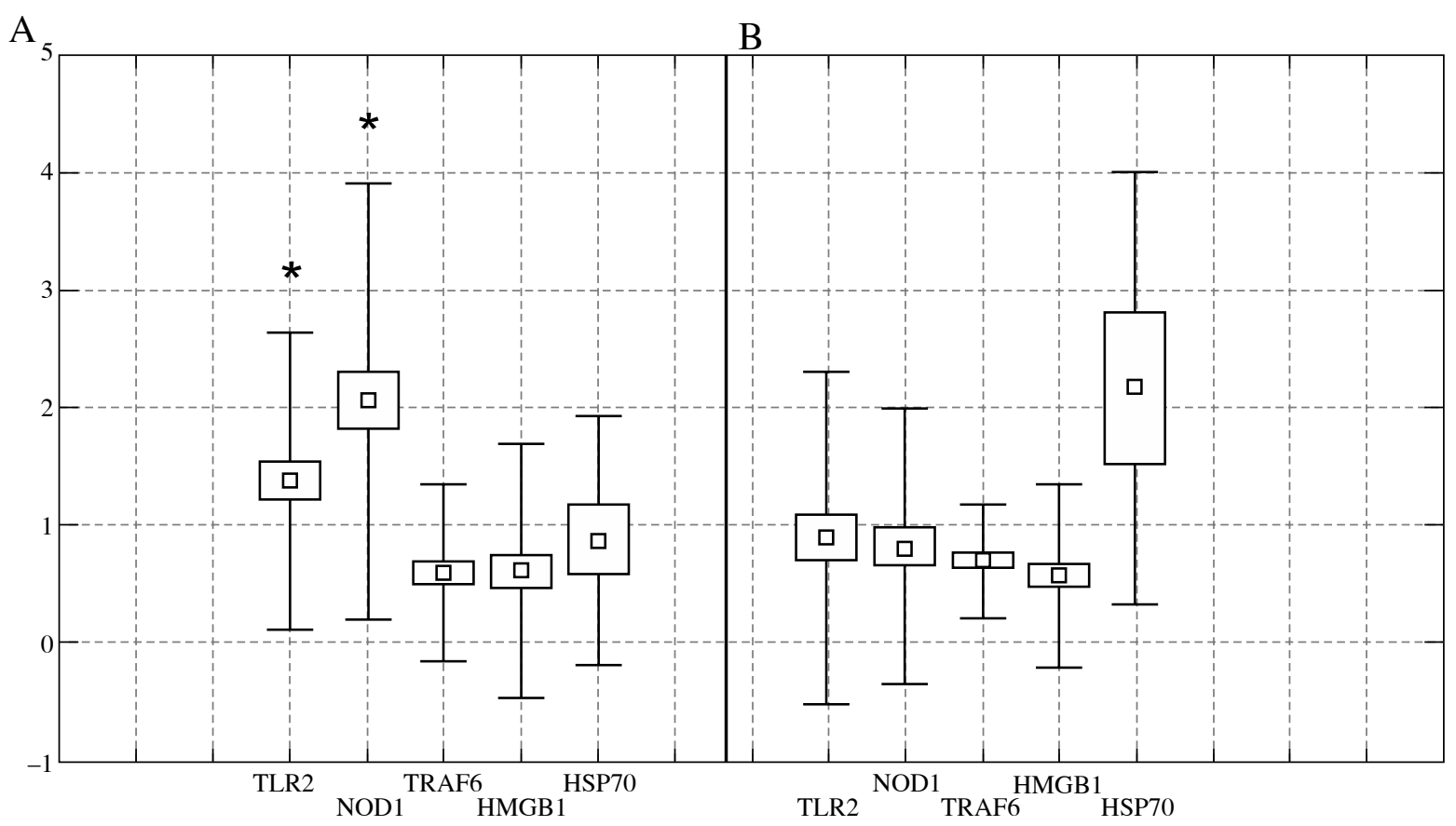

Fig. 4. Expression of TLR2, NOD1, TRAF6, HMGB1 and Hsp 70 genes in deceased patients with severe malnutrition (A) compared with patients with normal nutritional status or mild malnutrition $(\mathbf{B})(* p<0.05)$

dependent on the severity of the infection and nutritional status. Increased activation of selected genes in peripheral blood leukocytes in all patients examined is an important diagnostic component of innate systemic inflammatory response disorders. Disorders of gene expression can influence the clinical outcome and should be diagnosed as early as possible, monitored and taken into account in an early line of therapy. As demonstrated by genetic studies of other authors, an increased gene expression concerns primarily the innate immune response and inflammatory response to trauma and infection [24, 90-95]. Organ damage and genomic changes are associated with up-regulation of integrin signaling, leukocyte extravasation, and Tolllike receptor signaling. Despite the differences in clinical signs, the genetic response to blunt trauma (referred to as "genomic storm") is similar to changes in the gene expression after burn injury or following the administration of endotoxin, and its intensity and duration are higher and 
longer in patients with complications. The results of our study showed that in a heterogeneous group of critically ill patients, not only the infection, but also the nutritional status can selectively alter the expression of the genes tested. Not without significance is the fact that in the current study, most of the patients were exposed to surgical trauma some time ago, presented severe infections and malnutrition and were admitted to the ICU from other surgical wards usually after a long treatment period, as they required intensive treatment because of complications and a high risk of death. The selective increase in the expression of genes encoding TLR2 NOD1 and Hsp70 proteins in all patients indicated that surgical trauma and infection were one of the major factors causing an increase in the mRNA level of these genes in peripheral blood leukocytes. It is known that a crucial role in an increased inflammatory response to injury and infection is played by recognition mechanisms of molecular patterns associated with pathogens through pattern-recognition receptors (PRRS). These include Toll-like receptors (TLRs), which importance in the pathogenesis of sepsis has been repeatedly underlined $[96,97]$. Not surprisingly, the results of our studies confirm earlier research of other authors [98-112]. Toll-like receptor signaling pathways were shown to be dynamically expressed in the course of sepsis and to correlate with sepsis severity; TLR signaling was differentially regulated in neutrophils and peripheral mononuclear cells of patients with sepsis, severe sepsis, and septic shock. Monocytes from trauma and septic patients expressed higher levels of TLR2 and TLR4 receptors than monocytes of healthy controls, but mortality in human sepsis was associated with down-regulation of TLR2 and CD14 receptors on blood monocytes, correlating with reduced cytokine (IL-6, IL-10 and TNF- $\alpha$ ) inducibility [113].

Comparing the group of critically ill patients with severe infections, with a group of subjects in a serious condition (APACHE II score of 19 points), but without septic infections, we found a decreased expression of TLR2 genes and HMGB1 and Hsp70 proteins in patients with severe sepsis and a high mortality rate. It can be assumed that a lower expression of these genes in patients with severe sepsis could be a negative prognostic indicator, but confirmation of this hypothesis requires further investigations. However, this raises a fundamental question whether and what clinical "consequences" and what kind of antimicrobial resistance disorders may cause a decrease in the expression of TLR2 genes and HMGB1 or Hsp70 proteins. At this stage of our research the answer can only be "indirect", and therefore, based on studies of other authors who evaluated the relationship between the expression level of TLR2, TLR4 and CD14 receptors on monocytes and severity of disease and mortality in sepsis, and found no correlation between the expression of these receptors and the severity of the patient status (according to APACHE II). This was presumably due to the lack of an increased TLR expression in most critically ill patients with the APACHE II score $>20$ points, as compared to patients in a better condition [114]. The same authors found that monocyte stimulation with LPS induced the expression of TLRs in surgical patients and the control group, but this response was not observed in septic patients, which might indicate a lower ability to respond to a secondary signal in septic patients [115]. These studies, however, did not consider an important factor influencing the expression of genes encoding TLRs, i.e., malnutrition that often accompanies severe septic states.

Reduction in the expression of genes encoding TLR2 proteins and HMGB1 and Hsp70 "alarmins" in the group of critically ill patients with severe infections is another indicator of the innate antibacterial immunity disorders and may be caused not only by the impaired maturation of the studied cells or immunosuppressive action of cells involved in inflammatory responses (e.g., myeloid-derived suppressor cells released from bone marrow in sepsis), but also protein-calorie deficiencies and depletion of nutritional substances important for the immune system cells, including amino acids such as glutamine, arginine and polyunsaturated fatty acids. The level of these substances in patients with sepsis, after major injury and following surgery is rapidly and substantially reduced (by up to $50 \%$ ), which may lead to disturbances in the innate antibacterial immune mechanisms and to the immunosuppression [116-121]. As established earlier, TLR2 receptors were found to mediate the effects of high mobility group box-1 protein (HMGB1) [122-126]. This protein is an important DNA-binding protein, stabilizing nucleosomes and facilitating NF- $\kappa \mathrm{B}$ activation and gene transcription [127, 128]. High mobility group box-1 protein modulates the inflammatory cascade in lipopolysaccharide-activated macrophages by inducing the production of pro-inflammatory cytokines, TNF- $\alpha$ and IL-1 $\beta$, while attenuating the release of anti-inflammatory mediators, IL-10 and TGF- $\beta 1$ [129]. It was shown that the concentration of HMGB1 in the peripheral blood correlates with the severity of trauma and is significantly higher in patients with multiple organ failure [130, 131]. Most recent research indicated that high HMGB 1 concentrations positively correlated with the severity of disease and mortality in patients from the ICUs with severe pneumonia [132]. Heat-shock proteins and HMGB1 protein, can be secreted by the cells and they can bind TLRs to regulate their functions. Interestingly, in the studies carried out in vivo and in vitro, Hsp70 was shown to induce anitibacterial response in both TLR $-2^{-/-}$and TLR- $4^{-/-}$mice [133]. In other study, Hsp70 inhibited lipopolysaccharide-induced NF- $\mathrm{KB}$ activation by interacting with TRAF6 and inhibiting its ubiquitination [134]. A reduced expression of HMGB1, TRAF6 and Hsp70 genes in the group of critically ill patients with severe malnutrition can indicate nutritional deficiencies and suppression of immune mechanisms. Therefore, it is hard not to assume 
that the abnormal gene expression presented in our study is a serious genetic disorder worsening innate antibacterial response in patients with severe sepsis.

Interestingly, the expression of the NOD1 receptor gene, tested in parallel in all patients and in the subgroup of patients with severe infections, remained significantly elevated. This could be a reaction to severe infection, including a compensatory response to antimicrobial immunity disorders caused by a decreased expression of other genes. This mechanism may serve to preserve the host ability to mount an immune response to bacteria via NOD signaling even in the TLR gene down-regulated state. TLRs and NOD1/NOD2 collaborate with one another in mounting and balancing an efficient innate immune response to microbial pathogens. On the other hand, it can be assumed that the expression of this gene encoding an intracellular receptor (expressed mainly in the cytosol) was less sensitive to malnutrition compared to other genes, as indicated by its increased expression also in patients with severe malnutrition who were recruited from the same group of subjects with severe infections. A separate problem is the heterogeneity of the study groups and the differences in the impact of microorganisms on NOD and TLR receptors, which could also affect gene expression. Nucleotide-binding oligomerization domain is expressed in a wide variety of cell types of both haematopoietic and non-haematopoietic origin. They possess the ability (e.g., NLRs - NOD-like receptors: NOD1, NOD2) to bind LPS and bacterial peptidoglycan as well as to transfer a signal independently of TLRs, which also results in NF- $\kappa \mathrm{B}$ activation and stimulation of the expression of cytokine-coding genes (for NOD1: TNF- $\alpha$ and IL-6, and for NOD2: TNF- $\alpha$ and IL-1 $\beta$ ) and adhesive molecules [135]. NOD1 recognizes compounds of Gram-negative (meso-diaminopimelic acid with peptidoglycan) and some Gram-positive bacteria [136], whereas muramyl dipeptide is a ligand for NOD2, derived from the wall of Gram-positive and Gram-negative bacteria [137, 138]. NOD-like signaling is involved in the regulation of immune homeostasis in the gut. NOD2 deficiency in mice can lead to a compromised epithelial barrier and impaired immune response to commensal microbiota [139].

The changes of gene expression in patients with severe malnutrition, compared with the moderate malnutrition, were similar to those in the group with severe infections, because severe malnutrition was accompanied by severe sepsis. The results of this part of the study once more indicate that both severe sepsis and severe malnutrition may be important factors decreasing the expression of TLR2, HMGB1 and Hsp70 genes. Thus, the conclusion is that in order to maintain the antimicrobial activity of the cells studied, patients with sepsis and malnutrition need to be provided adequate amounts of protein and energy, which can be achieved by appropriate nutritional treatment $[37$, $38,71,140-142]$. However, it can be assumed that the ap- plication of TLR2-blocking drugs in these patients or inhibition of the activity of HMGB1 without early genetic diagnosis would be unfavorable [143-146]. Further research on the impact of the nutritional status on gene expression showed that the expression of TLR2 and NOD1 genes in patients with moderate malnutrition (patients with severe infections were predominant in this group) was significantly increased in comparison to those with mild malnutrition and normal nutritional status. A group of patients with moderate malnutrition, diagnosed with severe infections, is an interesting example of the impact of the nutritional status on gene expression. A better nutritional status in this group was probably one of the factors that contributed to TLR2 and NOD1 expression, although it is difficult to rule out the involvement of other factors, including the impact of trauma or severity of the infection. However, it should be reminded that the mortality rate in this group was significantly lower than in patients with severe malnutrition and severe infections. The results of these experiments, as well as the experiments in all patients, support the significant effect of both factors (infection and malnutrition) on the expression of the genes investigated. This hypothesis is confirmed by the increased expression of TLR2 and NOD1 genes in deceased patients with severe malnutrition and severe infections compared to the expression of these genes in patients with normal nutritional status or mild malnutrition and septic infections. In the group of patients who had died in the first week of intensive treatment, septic shock and multiple organ failure were the dominant factors that could have increased the expression of TLR2 and NOD1 genes, while the impact of severe malnutrition could have been weaker. More than half of these patients died due to complications of severe acute pancreatitis or septic complications after major cancer surgeries.

In summary, the results indicate that gene expression disorders can influence the clinical outcome and should be diagnosed as early as possible, monitored and considered in an early line of therapy. Without early genetic diagnostics of innate antimicrobial immunity disorders, attempts of its modulation may not be successful in the majority of ICU cases in specific clinical situations, because the gene expression changes depending on the severity of the patient condition, severity of infection and nutritional status. In malnourished septic patients with a reduced expression of the study genes, an important part of the adjunctive therapy to the primary line of treatment should be compensation of the deficit of energy, protein and other substances essential to the functioning of immune system cells (arginine, glutamine, polyunsaturated fatty acids, antioxidants). As regards the patients in a severe condition, burdened with the highest risk of early death who apart from severe malnutrition show an increased expression of genes of innate antibacterial response, apart from the primary therapy and nutrition enhancing functions of the immune system, an additional early blocking treatment of 
the expression of selected receptors (e.g., TLR2 and NOD1 receptors as potential targets for therapeutic intervention) should be considered.

This study was supported by the National Science Centre (NCN Poland, grant no. NN401 103340).

The authors declare no conflict of interest.

\section{References}

1. Angus DC, Linde-Zwirble WT, Lidicker J, et al. (2001): Epidemiology of severe sepsis in the United States: analysis of incidence, outcome, and associated costs of care. Crit Care Med 29: 1303-1310.

2. Husak L, Marcuzzi A, Herring J, et al. (2010): National Analysis of Sepsis Hospitalizations and Factors Contributing to Sepsis In-Hospital Mortality in Canada. Healthc Q 13 Spec No:35-41.13(Spec): 35-41.

3. Gierek D, Kuczera M, Dąbek J, et al. (2011): Analiza leczenia chorych z ciężką sepsą w Oddziale Anestezjologii i Intensywnej Terapii Górnośląskiego Centrum Medycznego. Anestezjol Inten Terap 43: 22-28.

4. Vincent JL, Sakr Y, Sprung CL, et al. (2006): Sepsis occurrence in acutely ill patients investigators. Sepsis in European intensive care units: results of the SOAP study. Crit Care Med 34: 344-353.

5. Martin GS, Mannino DM, Eaton S, Moss M (2003): The epidemiology of sepsis in the United State from 1979 through 2000. N Engl J Med 348: 1546-1554.

6. Riedemann NC, Guo RF, Ward PA (2003): The enigma of sepsis. J Clin Invest 112: 460-467

7. Mullard A (2011): Drug withdrawal sends critical care specialists back to basic. Lancet 378: 1760.

8. McCulloh R, Opal SM (2013): Human recombinant lactoferrin for sepsis too good to be true? Crit Care Med 41: 908-909.

9. Opal SM, Laterre PF, Francois B, et al. (2013): Effect of Eritoran, an antagonist of MD2-TLR4, on mortality in patients with severe sepsis. The ACCESS randomized trial. JAMA 309: 1154-1162.

10. Bone RC (1996): Immunologic dissonance: A continuing evolution in our understanding of the Systemic Inflammatory Response Syndrome (SIRS) and the Multiple Organ Dysfunction Syndrome (MODS). Ann Intern Med 125: 680-687.

11. Moore FA, Sauala A, Moore EE, et al. (1996): Postinjury Mulitple Organ Failure: A Bimodal Phenomenon. J Trauma 40: 501-512.

12. Murphy TJ, Paterson HM, Mannick JA, Lederer JA (2004): Injury, sepsis, and regulation of Toll-like receptor responses. J Leukoc Biol 75: 400-407.

13. Brochner AC, Toft P (2009): Pathophysiology of the systemic inflammatory response after major accidental trauma. Scand J Trauma Resusc Emerg Med 17: 43.

14. Gentile LF, Cuenca AG, Philip A, et al. (2012): Persistent inflammation and immunosuppression: A common syndrome and new horizon for surgical intensive care. J Trauma Acute Care Surg 72: 1491-1501.

15. Hotchkiss RS, Monneret G, Payen D (2013): Sepsis-induced immunosuppression: from cellular dysfunctions to immunotherapy. Nat Rev Immunol 13: 862-874.
16. Namath A, Patterson AJ (2009): Genetic polymorphisms in sepsis. Crit Care Clin 25: 835-856.

17. Namath A, Patterson AJ (2011): Genetic polymorphisms in sepsis. Crit Care Nurs Clin North Am 23: 181-202.

18. Dahmer MK, Randolph A, Vitali S, et al. (2005): Genetic polymorphisms in sepsis. Crit Care Med 6 (3 Suppl.): S61-S73.

19. Wang H, Wei Y, Zeng Y (2014): The association of polymorphisms of TLR4 and CD14 genes with susceptibility to sepsis in a Chinese population. Medical Genetics 15: 123, $1-9$.

20. Arcaroli J, Fessler MB, Abraham E (2005): Genetic polymorphisms and sepsis. Shock. 24: 300-312.

21. Markwart R, Condotta SA, Requardt RP, el al. (2014): Immunosuppression after sepsis: systemic inflammation and sepsis induce a loss of nadve T-cells but no enduring cell-autonomous defects in T-cell function. PLoS One 9: 1-13.

22. McCall CE, Yoza BK, Liu T, Gazzar EI (2010): Gene-specific epigenetic regulation in serious infections with systemic inflammation. J Innate Immun 2: 395-405.

23. Kumpf O, Schumann RR (2010): Genetic variation in innate immunity pathways and their potential contribution to the SIRS/CARS debate - evidence from human studies and animal models. J Innate Immun 2: 381-394.

24. Xiao W, Mindrinos MN, Seok J, et al. (2011): A genomic storm in critically injured humans. J Exp Med 208: 25812590.

25. Wischmeyer PE (2011): Malnutrition in the acutely ill patient: is it more than just protein and energy? S Afr J Clin Nutr 24: 1-7.

26. Hughes SM, Amadi B, Mwiya M, et al. (2009): Dendritic cell anergy results from endotoxemia in severe malnutrition. J Immunol 183: 2818-2826.

27. Cabrera-Perez J, Condotta SA, Badovinac VP, et al. (2014): Impact of sepsis on CD4 T cell immunity. J Leukoc Biol 96: 767-777.

28. Shubin NJ, Monaghan SF, Heffernan DS, et al. (2013): B and $\mathrm{T}$ lymphocyte attenuator expression on CD4+ T-cells associates with sepsis and subsequent infections in ICU patients. Critical Care 17: R276.

29. Neelemaat F, Meijers J, Kruizenga H, et al. (2011): Comparison of five malnutrition screening tools in one hospital inpatient sample. J Clin Nurs 20: 2144-2152.

30. Raslan M, Gonzalez MC, Dias MC, et al. (2011): Complementarity of Subjective Global Assessment (SGA) and Nutritional Risk Screening 2002 (NRS 2002) for predicting poor clinical outcomes in hospitalized patients. Clin Nutr 30: 49-53.

31. Fowler RA, Adhikari NK, Bhagwanjee S (2008): Clinical review: critical care in the global context-disparities in burden of illness, access, and economics. Crit Care 12: 1-6.

32. Nguyen YL, Angus DC, Boumendil A, Guidet B (2011): The challenge of admitting the very elderly to intensive care. Ann Intensive Care 1: 1-7.

33. Baccaro F, Moreno JB, Borlenghi C, et al. (2007): Subjective global assessment in the clinical setting. JPEN J Parenter Enteral Nutr 31: 406-409.

34. Singh H, Watt K, Veitch R, et al. (2006): Malnutrition is prevalent in hospitalized medical patients: are house staff identifying the malnourished patient? Nutrition 22: 350354. 
35. Norman K, Pichard C, Lochs H, Pirlich M (2008): Prognostic impact of disease-related malnutrition. Clin Nutr 27: $5-15$.

36. Marik PE, Zaloga GP (2010): Immunonutrition in high-risk surgical patients. A systematic review and analysis of the literature. JPEN J Parenter Enteral Nutr 34: 378-386.

37. Marik PE, Hooper M (2012): Immunonutrition in the critically ill. Immuno-Gastroenterology 1: 7-17.

38. McClave SA, Martindale RG, Vanek VW, et al. (2009): Guidelines for the Provision and Assessment of Nutrition Support Therapy in the Adult Critically Ill Patient: Society of Critical Care Medicine (SCCM) and American Society for Parenteral and Enteral Nutrition (A.S.P.E.N.) JPEN J Parenter Enteral Nutr 33: 277-316.

39. Vidal-Casariego A, Calleja-Fernández A, Villar-Taibo R, et all. (2014): Efficacy of arginine-enriched enteral formulas in the reduction of surgical complications in head and neck cancer: a systematic review and meta-analysis. Clin Nutr 33: 951-957.

40. Drover JW, Dhaliwal R, Weitzel L, et al. (2011): Perioperative use of arginine-supplemented diets: A systematic review of the evidence. J Am Coll Surg 212: 385-399.

41. Mizock BA (2010): Immunonutrition and critical illness: an update. Nutrition 26: 701-707.

42. Taylor B Joe Krenitsky J (2010): Nutrition in the Intensive Care Unit: Year in Review 2008-2009. JPEN J Parenter Enteral Nutr 34: 21-31.

43. Hegazi RA, Paul E Wischmeyer PE (2011): Clinical review: optimizing enteral nutrition for critically ill patients - a simple data-driven formula. Crit Care 15: 234.

44. Stechmiller JK, Childress B, Porter T (2004): Arginine immunonutrition in critically ill patients: A clinical dilemma. Am J Crit Care 13: 17-23.

45. Zhou M, Martindale RG (2007): Arginine in the critical care setting. J Nutr 137 (6 Suppl 2): 1687S-1692S.

46. Heyland DK, Dhaliwal R, Drover JW, et al. Canadian Critical Care Clinical Practice Guidelines Committee (2003): Canadian critical care clinical practice guidelines for nutrition support in mechanically ventilated, critically ill adult patients. JPEN J Parenter Enteral Nutr 27: 355-373.

47. Ortiz Leyba C, Montejo González JC, Vaquerizo Alonso C; Metabolism and Nutrition Working Group of the Spanish Society of Intensive Care Medicine andCoronary units (2011): Guidelines for specialized nutritional and metabolic support in the critically-ill patient: update. ConsensusSEMICYUC-SENPE: septic patient. Nutr Hosp 26 Suppl 2: 67-71.

48. McClave SA, Martindale RG, Vanek VW, et al. American Society for Parenteral and Enteral Nutrition board of directors, American College of Critical Care Medicine, Society of Critical Care Medicine (2009):. Guidelines for the provision and assessment of nutrition support therapy in the adult critically ill patient: Society of Critical Care Medicine (SCCM) and American Society for Parenteral and Enteral Nutrition (A.S.P.E.N.). JPEN J Parenter Enteral Nutr 33: 277-316.

49. McClave SA, Hurt RT (2010): Clinical guidelines and nutrition therapy: better understanding and greater application to patient care. Crit Care Clin 26: 451-466.

50. Wohlmuth C, Dünser MW, Wurzinger B, et al. (2010): Early fish oil supplementation and organ failure in patients with septic shock from abdominal infections: a propensity-matched cohort study. JPEN J Parenter Enteral Nutr 34: 431-437.
51. Lenox CE, Bauer JE (2013): Potential adverse effects of omega-3 fatty acids in dogs and cats. J Vet Intern Med 27: 217-226.

52. Calder PC, Jensen GL, Koletzko BV, et al. (2010): Lipid emulsions in Parenteral nutrition of intensive care patients: current thinking and future directions. Intensive Care Med 36: 735-749.

53. Heyland D, Muscedere J, Wischmeyer PE, et al. (2013): Canadian Critical Care Trials Group. A randomized trial of glutamine and antioxidants in critically ill patients. N Engl J Med 368: 1489-1497.

54. García-de-Lorenzo A, Denia R, Atlan P, et al. (2005): Parenteral nutrition providing a restricted amount of linoleic acid in severely burned patients: a randomized double-blind study of an olive oil-based lipid emulsion v. medium/longchain triacylglycerols. Br J Nutr 94: 221-230.

55. Huschak G, Zur Nieden K, Hoell T, et al. (2005): Olive oil based nutrition in multiple trauma patients: a pilot study. Intensive Care Med 31: 1202-1208.

56. Wanten GJA, Calder PC (2007): Immune modulation by parenteral lipid emulsions. Am J Clin Nutr 85: 1171-1184.

57. Singer P, Berger MM, Van den Berghe G, et al. (2009): ESPEN Guidelines on Parenteral Nutrition: Intensive care. Clin Nutr 28: 387-400.

58. Granja C, Póvoa P, Lobo C, et al. (2013): The predisposition, infection, response and organ failure (Piro) sepsis classification system: results of hospitalmortality using a novel concept and methodological approach. PLoS ONE 8: e53885.

59. de Groot B, Lameijer J, de Deckere ERJT, et al. (2014): The prognostic performance of the predisposition, infection, response and organ failure (PIRO) classification in high-risk and low-risk emergency department sepsis populations: comparison with clinical judgement and sepsis category. Emerg Med J 31: 292-300.

60. Howell MD, Talmor D, Schuetz P, et al. (2011): Proof of principle: The predisposition, infection, response, organ failure sepsis staging system. Crit Care Med 39: 322-327.

61. Desai KH, Tan ChS, Lekk JT, et al. (2011): Dissecting inflammatory complications in critically injured patients by within-patient gene expression changes: A longitudinal clinical genomic study. PLoS Med 8: e1001093.

62. Wong HR (2012): Clinical review: Sepsis and septic shockthe potential of gene arrays Critical Care 16: 204-212.

63. Cuenca AG, Gentile LF, Lopez MC, et al. (2013): Development of a genomic metric that can be rapidly used to predict clinical outcome in severely injured trauma patients. Crit Care Med 41: 1-20.

64. Talwar S, Munson PJ, Barrb J, et al. (2006): Gene expression profiles of peripheral blood leukocytes after endotoxin challenge in humans. Physiol Genomics 25: 203-215.

65. Castellheim A, Brekke OL, Espevik T, et al. (2009): Innate immune responses to danger signals in systemic inflammatory syndrome and sepsis. Scandinavian Journal of Immunology 69: 479-491.

66. Zhang QM, Raoof Y, Chen Y, et al. (2010): Circulating mitochondrial DAMPs cause inflammatory response to injury. Nature 464: 104-107.

67. Punnet P, Yap CT, Wong Y, et al. (2010): SphK1 regulates proinflammatory responses associated with endotoxin and polymicrobial sepsis. Science 328: 1290-1294.

68. Fock RA, Vinolo MAR, Sá Rocha VM, et al. (2007) Protein-energy malnutrition decreases the expression of TLR-4/ 
MD-2 and CD14 receptors in peritoneal macrophages and reduces the synthesis of TNF- $\alpha$ in response to lipopolysaccharide (LPS) in mice. Cytokine 40: 105-114.

69. Wischmeyer PE (2007): Glutamine: mode of action in critical illness. Crit Care Med 35 (9 suppl): S541-544.

70. Garrel D, Patenaude J, Nedelec B, et al. (2003): Decreased mortality and infectious morbidity in adult burn patients given enteral glutamine supplements: a prospective, controlled, randomized clinical trial. Crit Care Med 31: 2444-2449.

71. Kreymann KG, Berger MM, Neutz NE, et al. (2006): ESPEN guidelines on enteral nutrition: Intensive care. Clin Nutr 25: 210-223.

72. Dutertius YM, Meguid MM, Pichard C (2009): Advancing from immunonutrition to pharmaconutrition:a gigantic challenge. Curr Opin Clin Nutr Metab Care 12: 398-403.

73. Kessel A, Toubi E, Pavlotzky E, et al. (2008): Treatment with glutamine is associated with down-regulation of Tolllike receptor- 4 and myeloid differentiation factor 88 expression and decrease in intestinal mucosal injury caused by lipopolysaccharide endotoxaemia in a rat. Clin Exp Immunol 151: 341-347.

74. Newsholme P (2001): Why is L-Glutamine metabolism important to cells of the immune system in health, postinjury, surgery or infection? J Nutr 131 (9 Suppl): 2515S-2522S.

75. Singleton K, Beckey D, Virginia E, et al. (2005): Glutamine prevents activation of NF- $\mathrm{KB}$ and stress kinase pathways, attenuates inflammatory cytokine release, and prevents acute respiratory distress syndrome (ARDS) following sepsis. Shock 24: 583-589.

76. Berger MM, Chioléro RL (2007): Antioxidant supplementation in sepsis and systemic inflammatory response syndrome. Crit Care Med 35 (9 Suppl): S584-S590.

77. Sukhotnik I, Agam M, Shamir R, et al. (2007): Oral glutamine prevents gut mucosal injury and improves mucosal recovery following lipopolysaccharide endotoxemia in a rat. J Surg Res 143: 379-384.

78. Sukhotnik I, Mogilner J, Krausz MM, et al. (2004): Oral arginine reduces gut mucosal injury caused by lipopolysaccharide endotoxemia in rat. J Surg Res 122: 256-262.

79. Sukhotnik I, Pollak Y, Coran AG (2014): Glutamine attenuates the inhibitory effect of methotrexate on TLR signaling during intestinal chemotherapy-induced mucositis in a rat. Nutr Metab (Lond) 11: 17.

80. Taniguchi Y, Yoshioka N, Nakata K, et al. (2009): Mechanism for maintaining homeostasis in the immune system of the intestine. Anticancer Res 29: 4855-4860.

81. Kędziora S , Słotwinski R, Dąbrowska A, et al. (2012): Glutamine abolishes the TLR-4 gene expression levels in pancreatic cancer patients: a preliminary study. Centr Eur J Immunol 37: 350-354.

82. Słotwiński R, Dąbrowska A, Lech G, et al. (2014): Gene expression disorders of innate antibacterial signaling pathway in pancreatic cancer patients: implications for leukocyte dysfunction and tumor progression. Cent Eur J Immunol 39: 498-507.

83. Kondrup J, Rasmussen HH, Hamberg O, Stanga Z (2003): ESPEN working group. Nutritional risk screening (NRS 2002): new method based on an analysis of controlled clinical trials. Clinical Nutrition 22: 321-336.

84. Baker JP, Detsky AS, Wesson DE, et al. (1982): Nutritional assessment: a comparison of clinical judgwmant and objective measures. N Engl J Med 306: 969-972.
85. Bone RC, Balk RA; Cerra FB, et al. (1992): Definitions for sepsis and organ failure and guidelines for the use of innovative therapies in sepsis. The ACCP/SCCM Consensus Conference Committee. American Collage of Chest Physicians/ Society of Critical Care Medicine. Chest 101: 1644-1655.

86. Levy MM, Fink MP, Marshall JC, et al. (2003): 2001 SCCM/ESICM/ACCP/ ATS/SIS international sepsis definitions conference. Crit Care Med 31: 1250-1256.

87. Dellinger RP, Levy MM, Rhodes A, et al. (2013): Surviving Sepsis Campaign: International Guidelines for Management of Severe Sepsis and Septic Shock, 2012. Intensive Care Med 39: 165-228.

88. Livak KJ, Schmittgen TD (2001): Analysis of relative gene expression data using real-time quantitative PCR and 2(-Delta Delta C (T)) method. Methods 25: 402-408.

89. Słotwiński R, Olszewski WL, Słodkowski M, et al. (2007): Can the interleukin-1 receptor antagonist (IL-1ra) be a marker of anti-inflammatory response to enteral immunonutrition in malnourished patients after pancreaticoduodenectomy? JOP 8: 759-769.

90. Calvano SE, Xiao W, Richards DR, et al. (2005): A network-based analysis of systemic inflammation in humans. Nature 437: 1032-1037.

91. Foteinou PT, Calvano SE, Lowry SF, Androulakis IP (2009):Modeling endotoxin-induced systemic inflammation using an indirect response approach. Math Biosci 217: 27-42.

92. Digiandomenico A, Veach R A, Zienkiewicz J, et al. (2014) : The "Genomic Storm" induced by bacterial endotoxin is calmed by a nuclear transport modifier that attenuates localized and systemic inflammation. PLoS ONE 9: e110183.

93. Hawiger J, Musser JM (2011): How to approach genome wars in sepsis? Crit Care 15: 1007.

94. Wong H R (2013): Genome-wide expression profiling in pediatric septic shock. Pediatric Research 73: 564-599.

95. Cuenca AG, Gentile LF, Lopez MC, et al. (2013): Development of a genomic metric that can be rapidly used to predict clinical outcome in severely injured trauma patients. Crit Care Med 41: 1175-1185.

96. Słotwiński R, Słotwińska S, Kędziora S, et al. (2011): Innate immunity signaling pathways: links between immunonutrition and responses to sepsis. Arch Immunol Ther Exp 59: 79-87.

97. Tsujimoto H, Ono S, Efron PA, et al. (2008): Role of Tolllike receptors in the development of sepsis. Shock 29: 315 321.

98. Adib-Conquy M, Cavaillon JM (2007): Stress molecules in sepsis and systemic inflammatory response syndrome. FEBS Letters 581: 3723-3733.

99. Sabroe I, Read RC, Whyte MKB, et al. (2003): Complex questions remain toll-like receptors in health and disease. J Immunol 171: 1630-1635.

100. Armstrong L, Medford ALR, Hunter KJ, et al. (2004): Differential expression of Toll-like receptor (TLR)-2 and TLR4 on monocytes in human sepsis. Clin Exp Immunol 136: 312-319.

101. Härter L, Mica L, Stocker R, et al. (2004): Increased expression of toll-like receptor- 2 and -4 on leukocytes from patients with sepsis. Shock 22: 403-409.

102. Skinner NA, MacIsaac CM, Hamilton JA, Visvanathan K (2005): Regulation of Toll-like receptor (TLR)2 and TLR4 on CD14dimCD16+ monocytes in response to sepsis-related antigens. Clin Exp Immunol 141: 270-278. 
103. Williams, DL, Ha T, Li C, et al. (2003): Modulation of tissue Toll-like receptor 2 and 4 during the early phases of polymicrobial sepsis correlates with mortality. Crit Care Med 31: 1808-1818.

104. Johnson SB, Matthew Lissauer M, Bochicchio GV, et al. (2007): Gene expression profiles differentiate between sterile SIRS and early sepsis. Ann Surg 245: 611-621.

105. Fahy RJ, Exline MR, Gavrilin MA, et al. (2008): Inflammasome mRNA expression in human monocytes during early septic shock. Am J Respir Crit Care Med 177: 983-988.

106. Kanneganti T-D, Lamkanfi M, Nunez G (2007): Intracellular NOD-like receptors in host defense and disease. Immunity $27: 549-559$.

107. Clarke TB, Davis KM, Lysenko ES, et al. (2010): Recognition of peptidoglycan from the microbiota by Nod1 enhances systemic innate immunity. Nat Med 16: 228-231.

108. Delogu G, Lo Bosco L, Marandola M, et al. (1997): Heat shock protein (HSP70) expression in septic patients. J Crit Care 12: 188-192.

109. Singleton KD, Wischmeyer PE (2006): Effects of HSP70.1/3 gene knockout on acute respiratory distress syndrome and the inflammatory response following sepsis. Am J Physiol Lung Cell Mol Physiol 290: L956-L961.

110. Weiss YG, Bromberg Z, Raj N, et al. (2007): Enhanced heat shock protein 70 expression alters proteasomal degradation of IкB kinase in experimental acute respiratory distress syndrome. Crit Care Med 35: 2128-2138.

111. Hashiguchi N, Ogura H, Tanaka H, et al. (2001): Enhanced expression of heat shock proteins in activated polymorphonuclear leukocytes in patients with sepsis. J Trauma 51: 1104-1109.

112. Gelain DP, de Bittencourt Pasquali MA, Comim CM, et al. (2011): Serum heat shock protein 70 levels, oxidant status, and mortality in sepsis. Shock 35: 466-470.

113. Schaaf B, Luitjens K Goldmann T, et al. (2009): Mortality in human sepsis is associated with downregulation of Tolllike receptor 2 and CD14 expression on blood monocytes. Diagn Pathol 4: 12.

114. Tsujimoto H, Ono S, Majima T, et al. (2005): Neutrophil elastaze, MIP-2 and TLR-4 expression Turing human and experimental sepsis. Shock 23: 39-44.

115. Tsujimoto H, Ono S, Majima, et al. (2006): Differential Toll-like receptor expression after ex vivo lipopolysaccharide exposure in patients with sepsis and following surgical stress. Clin Immunol 119: 180-187.

116. Askanazi J, Carpentier YA, Michelsen CB, et al. (1980): Muscle and plasma amino acids following injury: influence of intercurrent infection. Ann Surg 192: 78-85.

117. Oudemans-van Straaten HM, Bosman RJ, Treskes M, et al. (2001): Plasma glutamine depletion and patient outcome in acute ICU admissions. Intensive Care Med 27: 84-90.

118. Yeh S-L, Lai Y-N, Shang H-F, et al. (2004): Effects of glutamine supplementation on innate immune response in rats with gut-derived sepsis. Br J Nutr 2004; 91: 423-429..

119. Pérez-Bárcena J, Regueiro V, Marsé P, et al. (2008): Glutamine as a modulator of the immune system of critical care patients: effect on Toll-like receptor expression. A preliminary study. Nutrition 4: 522-527.

120. Pérez-Bárcena J, Crespí C, Regueiro V, et al. (2010): Lack of effect of glutamine administration to boost the innate immune system response in trauma patients in the intensive care unit. Crit Care 14: R233.
121. Chen QH, Yang Y, He HL, et al. (2014): The effect of glutamine therapy on outcomes in critically ill patients: a meta-analysis of randomized controlled trials. Crit Care 18: R8.

122. Yu M, Wang H, Ding A (2006): HMGB1 signals through toll-like receptor (TLR) 4 and TLR2. Shock 26: 174-179.

123. Park JS, Svetkauskaite D, He Q, et al. (2004): Involvement of Toll-like receptors 2 and 4 in cellular activation by high mobility group box 1 protein. J Biol Chem 279: 7370-7377.

124. Park JS, Gamboni-Robertson F, He Q (2006): High mobility group box 1 protein interacts with multiple Toll-like receptors. Am J Physiol Cell Physiol 290: C917-C924.

125. Hreggvidsdóttir HS, Lundberg AM, Aveberger AC (2012): High mobility group box protein 1 (HMGB1)-partner molecule complexes enhance cytokine production by signaling through the partner molecule receptor. Mol Med 27: 224230.

126. Kang R, Chen R, Zhang Q, et al. (2014): HMGB1 in health and disease. Mol Aspects Med 40: 1-116.

127. Bustin M (1999): Regulation of DNA-dependent activities by the functional motifs of the high-mobility-group chromosomal protein. Mol Cell Biol 19: 5237-5246.

128. Wang H, Yang H, Czura, et al. (2001): HMGB1 as a late mediator of lethal systemic inflammation. Am J Respir Crit Care Med 164: 1768-1773.

129. El Gazzar M (2007): HMGB1 modulates inflammatory responses in LPS-activated macrophages. Inflamm Res 56: $162-167$.

130. Schierrbeck H, Wahamaa H, Andersson U, et al. (2010): Immunomodulatoty drugs regulate HMGB1 release from activated human monocytes. Mol Med 16: 343-351.

131. Cohen MJ, Brohi K, Calfee SC, et al. (2009): Early release of high mobility group box nuclear protein 1 after severe trauma in humans; role of injury severity and tissue hypoperfusion. Crit Care 13: R174.

132. Tseng CC, Fang WF, Leung SY, et al. (2014): Impact of serum biomarkers and clinical factors on Intensive Care Unit mortality and 6-month outcome in relatively healthy patients with severe pneumonia and Acute Respiratory Distress Syndrome. Dis Markers 2014: 804654.

133. Blander JM, Medzhitov R (2004): Regulation of phagosome maturation by signals from Toll-like receptors. Science 304: 1014-1018.

134. Chen H, Wu Y, Zhang Y, et al. (2006): Hsp70 inhibits lipopolysaccharide-induced NF- $\mathrm{KB}$ activation by interacting with TRAF6 and inhibiting its ubiquitination. FEBS Letters 580: 3145-3152.

135. Sońdka Z, Tretyn A, Szeliga J, et al. (2006): Involvement of leucine Roch repeats (LRR) domain containing proteins in molecular mechanisms of inna te immunity of plants and Animals. Post Biol Kom 33: 635-656.

136. Chamaillard M, Hashimoto M, Horie E, et al. (2003): An essential role for Nod1 in host recognition of bacterial peptidoglycan containing diaminopimelic acid. Nat Immunol 4: 702-707.

137. Girardin SE, Boneca IG, Viala J, et al. (2003): Nod2 is a general sensor of peptidoglycan through muramyl dipeptive (MDP) detection. J Biol Chem 278: 8869-8872.

138. Lee JY, Hwang DH (2006): The modulation of inflammatory gene expression by lipids: mediation through Toll-like receptors. Mol Cells 21: 174-185.

139. Jiang W, Wang X, Zeng B, et al. (2013): Recognition of gut microbiota by NOD2 is essential for the homeostasis 
of intestinal intraepithelial lymphocytes. J Exp Med 210: 2465-2476.

140. Elke G, Wang M, Weiler N, et al. (2014): Close to recommended caloric and protein intake by enteral nutrition is associated with better clinical outcome of critically ill septic patients: secondary analysis of a large international nutrition database. Crit Care 18: R29.

141. Ville S, Chiolero RL, Bollmann MD, et al. (2005): Negative impact of hypocaloric feeding and energy balance on clinical outcome in ICU patients. Clinical Nutrition 24: 502-509.

142. Marik PE, Zaloga GP (2008): Immunonutrition in critically ill patients: a systematic review and analysis of the literature. Intensive Care Med 34: 1980-1990.

143. Meng G, Grabiec A, Rutz M, et al. (2005): Murine TLR2 expression analysis and systemic antagonism by usage of specific monoclonal antibodies. Immunol Lett 98: 200-207.

144. Roger T, Calandra T (2009): TLR2-mediated neutrophil depletion exacerbates bacterial sepsis. PNAS 106: 6889-6890.

145. Huang L, Yao Y, Sheng Z (2012): Novel insights for high mobility group box 1 protein-mediated cellular immune response in sepsis: A systemic review. World J Emerg Med 3: $165-171$.

146. Kim TH, Yoon SJ, Lee SM (2012): Genipin attenuates sepsis by inhibiting Toll-like receptor signaling. Mol Med 18: 455-465. 